\title{
Two new species of sooty moulds, Capnodium coffeicola and Conidiocarpus plumeriae in Capnodiaceae
}

\section{Hongsanan $S^{1,2,3}$, Tian $Q^{1,2,3}$, Hyde $\mathrm{KD}^{1,2,3}$ and Chomnunti $\mathbf{P}^{3,4}$}

\author{
${ }^{1}$ World Agroforestry Centre, East and Central Asia, Kunming 650201, Yunnan, China \\ ${ }^{2}$ Key Laboratory of Economic Plants and Biotechnology, Kunming Institute of Botany, Chinese Academy of Sciences, \\ Lanhei Road No 132, Panlong District, Kunming, Yunnan Province, 650201, PR China \\ ${ }^{3}$ Center of Excellence in Fungal Research, Mae Fah Luang University, Chiang Rai, 57100, Thailand \\ ${ }^{4}$ School of Science, Mae Fah Luang University, Chiang Rai, 57100, Thailand
}

Hongsanan S, Tian Q, Hyde KD, Chomnunti P. 2015 - Two new species of sooty moulds, Capnodium coffeicola and Conidiocarpus plumeriae in Capnodiaceae. Mycosphere 6(6), 814-824, Doi 10.5943/mycosphere/6/6/14

\begin{abstract}
Capnodiaceae is believed to be the largest family containing sooty mould species, the taxa of which can cause chlorosis, plant stunting disease, and marketability problems, due to black mycelium coating the surface of host. Presently, little molecular data are available for species of Capnodiaceae in GenBank, thus more collections and sequence data are needed to improve the understanding of genera and species boundaries in this family. "Sooty mould"-like taxa, appearing as black colonies on the surface of leaves, were collected in Chiang Rai Province, Thailand. Taxa were studied based on morphological characters and molecular analyses. A phylogenetic tree using combined LSU and ITS sequence data generated by Maximum likelihood analyses (LSU and ITS) indicated that the new species, Capnodium coffeicola and Conidiocarpus plumeriae, belong in Capnodiaceae. We introduce the two new species base on morphological characterization and phylogenetic analyses.
\end{abstract}

Key words - Capnodiales - Dothideomycetes - Phylogeny - Sooty moulds - Taxonomy

\section{Introduction}

Sooty moulds belong in seven families, which are Antennulariellaceae Woron., Capnodiaceae Höhn. ex Theiss., Chaetothyriaceae Hansf. ex M.E. Barr, Coccodiniaceae Höhn. ex O.E. Erikss., Euantennariaceae S. Hughes \& Corlett ex S. Hughes, Metacapnodiaceae S. Hughes \& Corlett and Trichomeriaceae Chomnunti \& K.D. Hyde (Reynolds 1998, Winka et al. 1998, Hughes \& Seifert 2012, Hyde et al. 2013, Chomnunti et al. 2014). They occur on various hosts, mainly forming a thin, superficial, network of dark mycelium on the surface of branches, flowers, fruits, leaves, and stems (Hughes 1976, Faull et al. 2002, Hyde et al. 2013, Chomnunti et al. 2014), and should not be confused with Asterinales M.E. Barr ex D. Hawksw. \& O.E. Erikss. and Meliolales Gäum. ex D. Hawksw. \& O.E. Erikss, which cause web-like, black colonies on leaves and cause minor damage to host plants by penetrating host cells for the uptake of nutrients (Ariyawansa et al. 2015, Hongsanan et al. 2014a, 2015a). Typically, sooty moulds reduce photosynthesis ability of plants through the mycelium coating; they can cause chlorosis under the mycelia, plant-stunting disease, low-yield, and marketability problems (Chomnunti et al. 2014). 
Sooty moulds have a wide distribution, and are most common in tropical and subtropical regions (Chomnunti et al. 2014).

Capnodiaceae is the most common family of sooty moulds, which is placed in the order Capnodiales, class Dothideomycetes (Batista \& Ciferri 1963, Hughes 1972, Crous et al. 2009a, b, Schoch et al. 2009, Chomnunti et al. 2011, 2014, Hyde et al. 2013, Wijayawardene et al. 2014, Liu et al. 2015). This family was introduced by Höhnel (1910), and later validated by Theissen (1916) and the generic type is Capnodium Mont. The family is characterized by superficial, septate, dark brown hyphae, forming a thin mycelial network on the surface of hosts, bitunicate asci, the sexual and asexual morphs can be found in the same or different hosts, however, for some the sexual morph is unknown (Chomnunti et al. 2011, 2014, Hyde et al. 2013). The asexual morphs form elongated pycnidia, with short or long narrow necks, have a conspicuous oval swelling near the base, middle or apex of the pycnidia, and produce hyaline conidia inside the swollen part (Chomnunti et al. 2011). Crous et al. (2009a, b) placed three genera in Capnodiaceae based on their phylogenetic analyses. They also noted that Capnodiales probably contains diverse lineages, and some of these might need to be established as new families. There are presently not enough sequence data to define a new family, thus more collections and sequence data are needed. Chomnunti et al. (2011) used LSU and SSU rRNA sequence data to classify genera and species in Capnodiaceae, and concluded, based on morphology and phylogeny, that this family contains four genera; Capnodium, Leptoxyphium Speg., Phragmocapnias Theiss. \& Syd. and Scorias Fr. Liu et al. (2015) introduced a new genus in Capnodiaceae (Chaetocapnodium Hongsanan \& K.D. Hyde), and a new species of Phragmocapnias (Phragmocapnias philippinensis Hongsanan \& K.D. Hyde).

Conidiocarpus is the asexual morph of Phragmocapnias which was introduced by Woronichin in Jaczewski (1917); the type species is Conidiocarpus caucasicus Woron. However, Batista \& Ciferri (1963) cited C. penzigii Woron. which was introduced in 1926, as the type species (Hughes 1976). There are several publications noting that the genus Conidiocarpus was introduced in 1926 based on the type species C. penzigii, thus it was synonymized under Phragmocapnias (sexual morph) in many publications. Bose et al. (2014) followed the discussion in Hughes (1976), and they transferred species in Phragmocapnias to Conidiocarpus based on the rules of nomenclatural priority. There are 11 species of, and 386 hits for Phragmocapnias in Index Fungorum (2016) and Google respectively and 10 species of, and 106 hits for Conidiocarpus. We therefore agree with Bose et al. (2014), that Conidiocarpus should be used over Phragmocapnias, for these linked genera. With the exception of Phragmocapnias philippinensis, all species in Phragmocapnias were transferred to Conidiocarpus by Bose et al. (2014). Thus herein we synonymize Phragmocapnias philippinensis under Conidiocarpus philippinensis (Hongsanan \& K.D. Hyde) Hongsanan \& K.D. Hyde.

In this study, we introduce two new species, Capnodium coffeicola and Conidiocarpus plumeriae in Capnodiaceae. The new taxa are compared morphologically with other species in Capnodiales. The introductions of Capnodium coffeicola and Conidiocarpus plumeriae are also supported by phylogenetic analyses of the LSU and ITS sequence data.

\section{Materials \& Methods}

\section{Collections, isolation and morphology}

Specimens with "Sooty mould"-like taxa were collected in Chiang Rai Province, Thailand, and observed under a stereomicroscope. Ascomata were studied by free-hand section, and their morphology studied under a compound microscope (Nikon 80i), slides were preserved in lactoglycerol after photographing. Measurements were determined using Tarosoft (R) Image Frame Work v. 0.9.7. Single spore isolation was carried out using the methods in Chomnunti et al. (2014). Type specimens of the new species are deposited in the Mae Fah Luang University Herbarium (MFLU), Chiang Rai, Thailand, and ex-type cultures are deposited in Mae Fah Luang University Culture Collection (MFLUCC), and in Kunming Institute of Botany (KIB). Faces of fungi numbers 
and Index Fungorum numbers are provided as explained in Jayasiri et al. (2015) and Index Fungorum (2016).

\section{DNA isolation, amplification and sequencing}

DNA was extracted from mycelium using the Biospin Fungus Genomic DNA Extraction Kit-BSC14S1 (BioFlux ${ }^{\circledR}$, P.R. China); following the instructions. The conditions for the polymerase chain reaction (PCR) were determined using the primer pairs LROR/LR5 to amplify the large subunit region (LSU), and ITS1/ITS4 to amplify the internal transcribed spacer region (ITS). The amplification was carried with setting times and temperatures for the initial denaturation and the final extension period following Hongsanan et al. (2014b, 2015b). PCR products were checked on $1 \%$ agarose electrophoresis gels, and sequenced by Majorbio Co., China. Sequences generated for the new species are deposited in GenBank.

\section{Phylogenetic analysis}

Thirty-six sequences were downloaded from GenBank to supplement the dataset. Davidiella tassiana was selected as outgroup taxon (Table 1). The data set, including the new species, Capnodium coffeicola and Conidiocarpus plumeriae, were aligned by using MAFFT (Katoh et al. 2009), and checked manually using Bioedit (Hall 1999). Maximum likelihood analysis was carried out in raxmlGUIv.0.9b2 (Silvestro \& Michalak 2012). The search strategy was set to bootstrapping and the analysis performed using the GTRGAMMAI model. The number of replicates was inferred using the stopping criterion (Pattengale et al. 2009). The bootstrap values expressed from 1,000 repetitions by RAxML analysis which are equal or greater than $50 \%$ are given to the left of each node (Fig. 1). The model of evolution was performed in MrModeltest 2.2 (Nylander 2008). Posterior probabilities (PP) were set by MCMC sampling in MrBayes v3.1.2 (Huelsenbeck \& Ronquist 2001, Zhaxybayeva \& Gogarten 2002), following the details in Cai et al. (2006, 2008) and Hongsanan et al. (2014a, b). Posterior probabilities values (PP) from Bayesian analysis which are equal or greater than 0.90 are given the right of each node (Fig. 1). Phylogenetic trees were viewed using MEGA v5.2.1 (Tamura et al. 2011).

\section{Results}

\section{Phylogenetic analyses}

The large subunit ribosomal (LSU) and Internal transcribed spacer (ITS) sequences from 38 isolates of Capnodiaceae, Dissoconiaceae, Euantennariaceae and Mycosphaerellaceae, were included in the phylogenetic analysis; Davidiella tassiana is used as the outgroup taxon (Fig. 1). In the tree, the family Capnodiaceae is placed within Capnodiales under Dothideomycetes. The Capnodiaceae clade comprised 29 strains which belong in Antennariella Bat. \& Cif., Capnodium Mont., Conidioxyphium Bat. \& Cif., Leptoxyphium Speg., Microxiphium (Harv. ex Berk. \& Desm.) Thüm., Phragmocapnias, Polychaeton (Pers.) Lév., and Scorias Fr. (98\% ML, 1.0 PP). The Leptoxyphium clade comprised three strains of Leptoxyphium including Microxiphium citri (100\% ML, 1.0 PP), this result is similar to previous studies (Chomnunti et al. 2014, Liu et al. 2015). Four Capnodium strains clustered with species of Conidioxyphium and Microxiphium (97\% ML and 1.0 PP), furthermore five strains of Scorias are basal. Capnodium coffeicola clustered in a moderately supported clade within the genus Capnodium, and is separated from the other species. The new taxon Conidiocarpus plumeriae is closely related to $C$. betle (Syd. et al.) T. Bose, with high bootstrap support, but is a distinct species (100\% ML, 1.0 PP). Two representative strains of Dissoconiaceae clustered together with high bootstrap support (100\% ML, $1.0 \mathrm{PP})$ and are related to Capnodiaceae (78\% ML). Six strains of Mycosphaerellaceae grouped with high bootstrap support (100\% ML, 1.0 PP) and are closely related to the two strains of Euantennariaceae (91\% ML, $0.99 \mathrm{PP})$. These three families form a sister group to Capnodiaceae within the order Capnodiales. 
Table 1 Taxa used in the phylogenetic analysis with GenBank accession numbers (LSU and ITS) and species voucher/culture numbers.

\begin{tabular}{|c|c|c|c|}
\hline \multirow{2}{*}{ Species } & \multirow{2}{*}{$\begin{array}{c}\text { Voucher/culture } \\
\text { numbers }\end{array}$} & \multicolumn{2}{|c|}{ Accession numbers } \\
\hline & & LSU & ITS \\
\hline$\overline{\text { Antennariella placitae }}$ & CBS 124785 & GQ303299 & GQ303268 \\
\hline Capnodium coartatum & MFLUCC10-0069 & JN832614 & - \\
\hline Capnodium coartatum & MFLUCC10-0070 & JN832615 & - \\
\hline Capnodium coffeae & CBS 147.52 & GU214400 & AJ244239 \\
\hline Capnodium coffeicola & MFLUCC15-0206 & KU358920 & KU358921 \\
\hline Chaetocapnodium siamensis & MFLUCC13-0778 & KP744479 & - \\
\hline Conidioxyphium gardeniorum & CPC 14327 & GU301807 & - \\
\hline Davidiella tassiana & CBS 399.80 & - & $\mathrm{AJ} 244227$ \\
\hline Dissoconium aciculare & CBS 204.89 & GU214419 & AY725520 \\
\hline Leptoxyphium cacuminum & MFLUCC10-0049 & JN832602 & have \\
\hline Leptoxyphium kurandae & CPC:17274 & JF951170 & JF951150 \\
\hline Leptoxyphium madagascariense & CBS 124766 & GQ303308 & GQ303277 \\
\hline Microxyphium aciculiforme & CBS 892.73 & GU301847 & - \\
\hline Microxyphium citri & CBS 451.66 & GU301848 & - \\
\hline Microxyphium theae & CBS 202.30 & GU301849 & GU296178 \\
\hline Mycosphaerella ellipsoidea & CBS: 110843 & GQ852602 & AY725545 \\
\hline Mycosphaerella endophytica & CBS:114662 & GQ852603 & DQ302953 \\
\hline Mycosphaerella punctiformis & CBS 113265 & NG027571 & KF442502 \\
\hline Pallidocercospora irregulariramosa & CBS 111211 & KF902053 & KF901706 \\
\hline Conidiocarpus philippinensis & MFLUCC12-0110 & KP744503 & - \\
\hline Conidiocarpus plumeriae & MFLUCC15-0205 & KU358918 & KU358919 \\
\hline Conidiocarpus siamensis & MFLUCC10-0053 & JN832606 & KU358922 \\
\hline Conidiocarpus siamensis & MFLUCC10-0061 & JN832607 & KU358923 \\
\hline Conidiocarpus siamensis & MFLUCC10-0062 & JN832612 & KU358924 \\
\hline Conidiocarpus siamensis & MFLUCC10-0063 & JN832608 & KU358925 \\
\hline Conidiocarpus siamensis & MFLUCC10-0064 & JN832609 & KU358926 \\
\hline Conidiocarpus siamensis & MFLUCC10-0065 & JN832610 & KU358927 \\
\hline Conidiocarpus siamensis & MFLUCC10-0074 & JN832611 & KU358928 \\
\hline Polychaeton citri & CBS 116435 & GU214469 & GU214649 \\
\hline Ramichloridium apiculatum & CBS 156.59 & EU041848 & EU041791 \\
\hline Rasutoria pseudotsugae & rapssd & EF114704 & EF114687 \\
\hline Rasutoria tsugae & ratstk & EF114705 & EF114688 \\
\hline Scorias leucadendri & CBS 131318 & JQ044456 & JQ044437 \\
\hline Scorias spongiosa & AFTOL-ID 1594 & DQ678075 & - \\
\hline Scorias spongiosa & CBS 325.33 & - & GU214696 \\
\hline Scorias mangiferae & MFLUCC15-0230 & KT588603 & KT588604 \\
\hline
\end{tabular}

Conidiocarpus philippinensis (Hongsanan \& K.D. Hyde) Hongsanan \& K.D. Hyde, comb. nov. Index Fungorum: IF551807

Facesoffungi number: FoF01771

$\equiv$ Phragmocapnias philippinensis Hongsanan \& K.D. Hyde, in Liu et al., Fungal Diversity: 172:69 (2015)

Notes - This species was introduced in Liu et al. (2015) as Phragmocapnias philippinensis. Phylogenetic analyses indicated that it was placed in Capnodiaceae, however it did not cluster with others species in Phragmocapnias sensu stricto (Liu et al. 2015); the result is similar to our study. Based on morphology, Liu et al. (2015) stated that $P$. philippinensis is most similar to other species in Phragmocapnias, but differs in having 5-septate ascospores without a hyaline sheath, thus they introduced it as a new species. Bose et al. (2014) synonymized Phragmocapnias under Conidiocarpus, which was the oldest name of these linked genera. They transferred species of Phragmocapnias to Conidiocarpus, thus, herein we synonymize $P$. philippinensis under $C$. philippinensis. This may require new genus when more related species are found, but for the present we place it in Conidiocarpus sensu lato. 


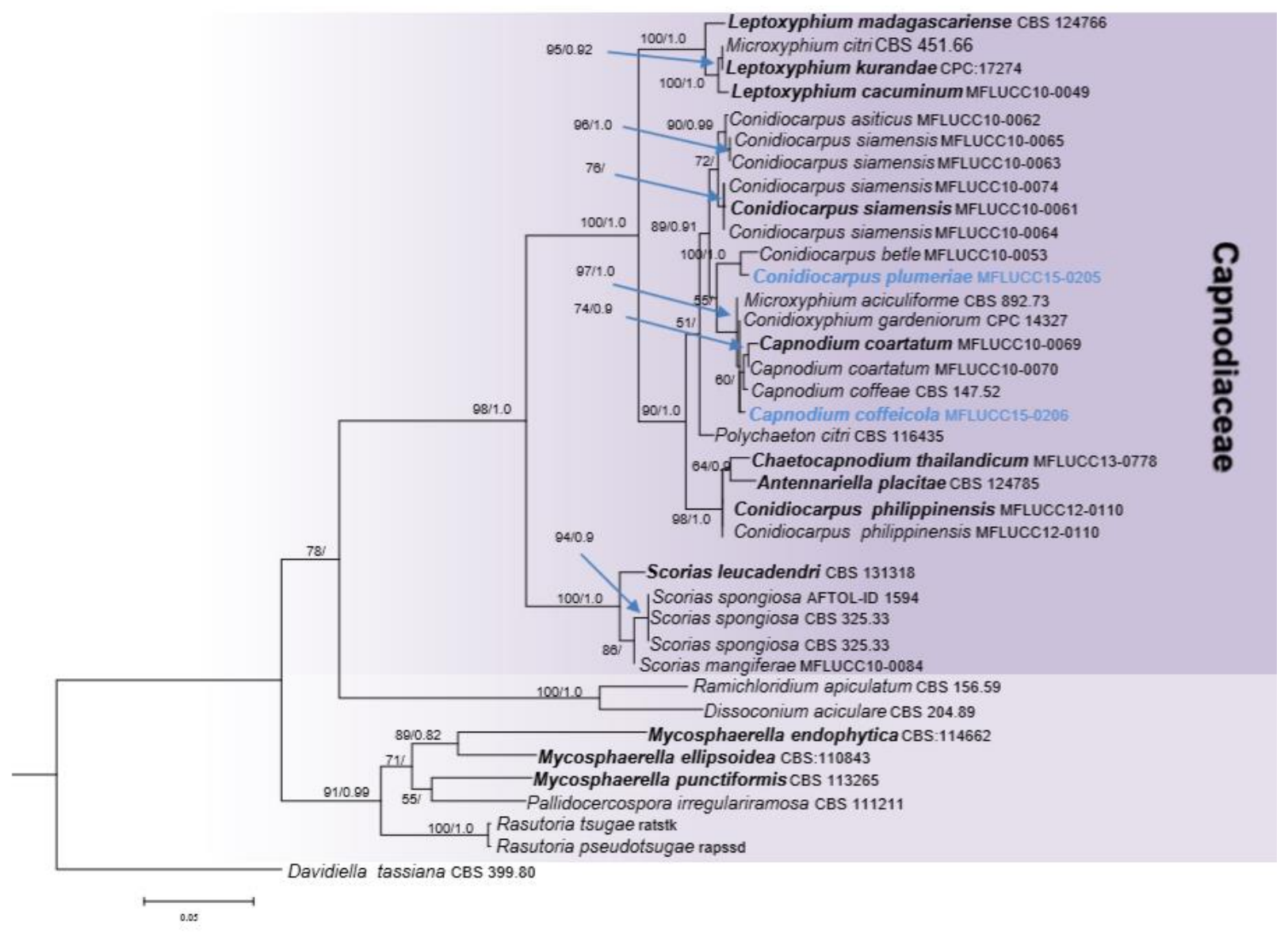

Fig. 1 - RAxML maximum likelihood phylogenetic tree generated from analysis of combined LSU and ITS sequence data. The first set of numbers above the nodes are RAxML bootstrap values equal or greater than $50 \%$. The second set of numbers above the nodes are Bayesian posterior probabilities, with values above 0.9 shown. Strain numbers are indicated after species names. Extypes strains are in black bold, new sequence data are in blue bold.

Capnodium coffeicola Hongsanan \& K.D. Hyde, sp. nov.

Fig. 2

Index Fungorum number: IF551802

Facesoffungi number: FoF01765

Etymology - coffeicola referring to the host on which the taxon was found.

Saprobic on sugary exudates from Coccus sp. (Coccidae, Insecta) growing on the surface of leaves, branches, and stems of Coffea sp. Thallus thin, dark brown, easily removed from the host surface, composed of cylindrical hyphae. Superficial hyphae 3-5 $\mu \mathrm{m}$ wide $(\bar{x}=4 \mu \mathrm{m}, \mathrm{n}=20)$, septate, constricted at the septum, branched, brown to dark brown, with subcylindrical hyphal cells. Sexual morph: Undetermined. Asexual morph: Pycnidia 165-178 $\mu \mathrm{m}$ long $(\bar{x}=170 \mu \mathrm{m}, \mathrm{n}=10)$, superficial, scattered or gregarious, blackish brown, cylindrical, swollen at the central part, 14-16 $\mu \mathrm{m}$ diam. $(\bar{x}=34 \mu \mathrm{m}, \mathrm{n}=10)$, stalk black, 19-24 long $\times 18-23 \mu \mathrm{m}$ diam. $(\bar{x}=23 \times 21 \mu \mathrm{m}, \mathrm{n}=20)$, wall comprising mostly cylindrical cells, the swollen part producing conidia inside. Ostiole 14-16 $\mu \mathrm{m}$ diam. $(\bar{x}=15 \mu \mathrm{m}, \mathrm{n}=10)$, surrounded by hyaline hyphae, $23-26 \times 2-3 \mu \mathrm{m}(\bar{x}=25 \times 2.5 \mu \mathrm{m}$, $\mathrm{n}=20$ ). Conidiogenous cells formed on the inner cell walls of the swollen part. Conidia $5-7 \times 1-3$ $\mu \mathrm{m}(\bar{x}=6 \times 2 \mu \mathrm{m}, \mathrm{n}=20)$, cylindrical to oblong, ends round, hyaline, smooth-walled.

Culture characters - Conidia germinating on PDA at $25-28^{\circ} \mathrm{C}$ for $12 \mathrm{~h}$ with dark, hyphae germinating from the conidia, septate, constricted at the septum, hyaline to grayish at the beginning, and become black to greenish later. Colonies slow growing, reaching $2 \mathrm{~cm}$ diam. after 5 days on PDA, colony superficial to erumpent, sometimes hyphae growing downwards and immersed into media, surface verrucose, velvety, branched at the margin, asexual structures produced in PDA after 3 days. 


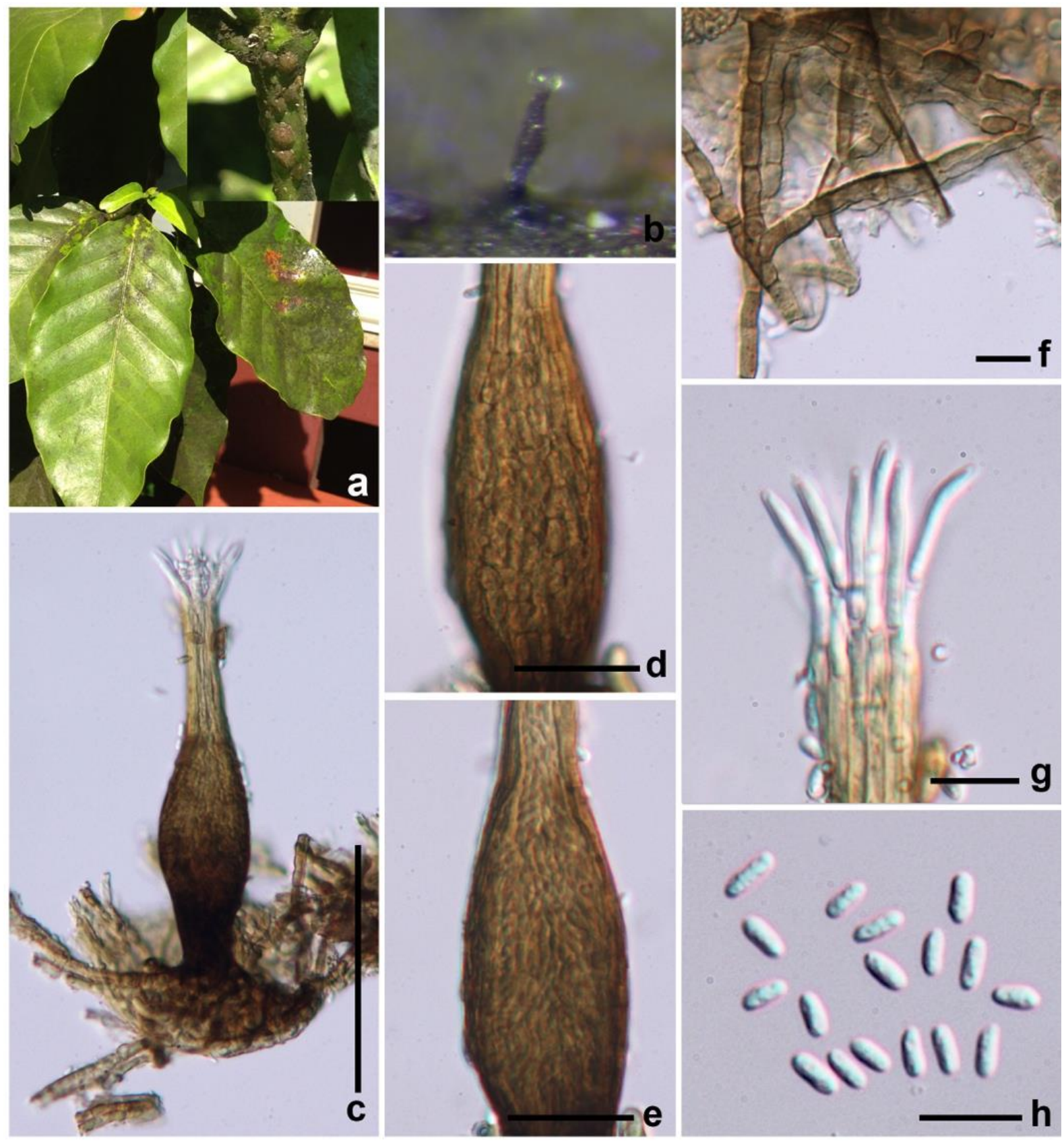

Fig. 2 - Capnodium coffeicola (holotype). a Substrate. b Pycnidia on surface of leaves. c Pycnidia when viewed in squash mount. $d$, e Cells wall of swollen part when viewed in squash mounts. $f$ Septate hyphae constricted at the septum. g Ostiole surrounded by hyaline hyphae. $\mathrm{k}$ Unicellular conidia. - Bars $c=100 \mu \mathrm{m}, \mathrm{d}, \mathrm{e}=20 \mu \mathrm{m}, \mathrm{f}-\mathrm{h} \mathrm{j}=10 \mu \mathrm{m}$.

Material examined - Thailand, Chiang Rai, Tasud, Mae Fah Luang University, AD2 building on leaves of Coffea sp., 4 January 2015, S. Hongsanan, PST2-1 (MFLU 15-3565, holotype); ibid. (isotype in KIB) - ex-type living culture in MFLUCC 15-0206.

Notes - Capnodium coffeicola is most typical of $C$. coartatum Chomnunti \& K.D. Hyde, but it has pycnidia with short and black stalks at the base, and is swollen at the central part, and cylindrical to oblong conidia, while $C$. coartatum has long and brown pycnidia, which are swollen at the base, lacks black and short stalks, and has ellipsoidal conidia. In addition, $C$. coffeicola is also similar to some species in the genus Conidiocarpus, based on its pycnidia being swollen at the central part of the pycnidium and a stalk in the lower swollen part. However, Capnodium coffeicola has a very short stalk and darkened lower swollen part. Phylogenetic analyses demonstrates that $C$. coffeicola belongs in Capnodium, within the family Capnodiaceae. 


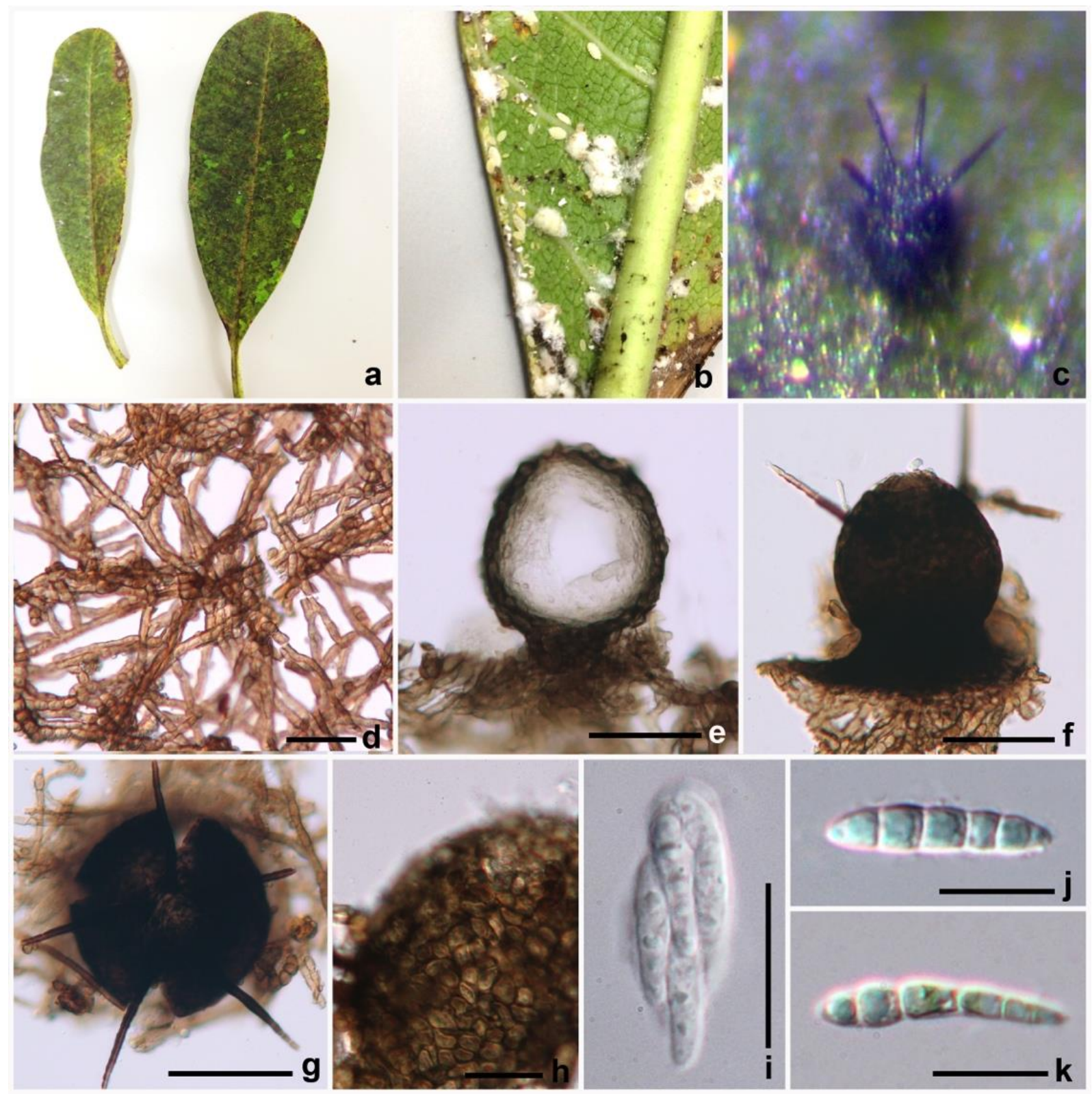

Fig. 3 - Conidiocarpus plumeriae (holotype). a Substrate. b Mealy bug on the lower surface of leaves. c Solitary ascomata on the surface of leaves. d Hyphal networks of $C$. plumeriae. e Section through ascoma. f, g Ascomata when viewed in squash mounts. $h$ Upper wall when viewed in squash mounts. i Asci with 8-spores. $\mathrm{j}$ Ascospores. $\mathrm{k}$ Ascospores in Melzer's reagent. - Bars e$\mathrm{g}=50 \mu \mathrm{m}, \mathrm{d}, \mathrm{h}, \mathrm{i}=20 \mu \mathrm{m}, \mathrm{k}, \mathrm{j}=10 \mu \mathrm{m}$.

Conidiocarpus plumeriae Hongsanan \& K.D. Hyde, sp. nov.

Fig. 3

Index Fungorum IF551805

Facesoffungi number FoF01766

Etymology - plumeriae referring to the host on which the taxon was found.

Saprobic on sugary exudates from Pseudococcus sp. (Pseudococcidae, Insecta), growing on the upper surface of Plumeria sp. Thallus thin, dark brown, easily removed from the host surface, composed of cylindrical hyphae. Superficial hyphae $5 \mu \mathrm{m}$ wide, branched, septate, slightly constricted and dark at the septum, pale brown to brown Sexual morph: Ascomata 90-95 $\mu \mathrm{m}$ diam. $(\bar{x}=94 \mu \mathrm{m}, \mathrm{n}=10$ ), superficial, solitary, subglobose, narrowly rounded above, constricted at the base, dark brown to black, ostiole present at maturity, thin-walled, with 3-4 ascomatal setae at the upper part of ascomata. Ascomatal setae 87-91 $\times 4-6 \mu \mathrm{m}(\bar{x}=89 \times 5 \mu \mathrm{m}, \mathrm{n}=10)$, aseptate, dark brown to reddish brown, but pale brown to hyaline at the apex. Peridium $10-13 \mu \mathrm{m}(\bar{x}=11 \mu \mathrm{m}$, 
$\mathrm{n}=10$ ), comprising cells of textura angularis, inner layer hyaline, outer layer dark brown to reddish brown. Hamathecium lacking pseudoparaphyses. Asci 37-42 × 13-16 $\mu \mathrm{m}(\bar{x}=39 \times 14 \mu \mathrm{m}, \mathrm{n}=10)$, 8-spored, bitunicate, fissitunicate, subcylindrical to obovoid, short pedicellate or sometimes apedicellate, ocular chamber not observed. Ascospores 19-25 $\times 4-6 \mu \mathrm{m}(\bar{x}=22 \times 5 \mu \mathrm{m}, \mathrm{n}=10)$, bi to tri-seriate, cylindrical to clavate, 5-septate, slightly constricted at the septum, with narrow ends, somewhat tapering towards the base, hyaline, smooth-walled. Asexual morph: Undetermined.

Culture characters - Ascospores germinating on PDA at $25-28^{\circ} \mathrm{C}$ for $12 \mathrm{~h}$ with dark, hyphae germinating at each cells of the ascospores, septate, constricted at the septum, hyaline to brown at the beginning, and become black to greenish, darker at the margin. Colonies slow growing reaching $2 \mathrm{~cm}$ diam. after 7 days on PDA, colony superficial to erumpent, surface verrucose, velvety.

Material examined - Thailand, Chiang Rai, Tasud, Mae Fah Luang University, AD2 building, on leaves of Plumeria sp., 10 January 2015, C. Singhapop, PST1-2 (MFLU 15-3564, holotype); ibid. (isotype in KIB) - ex-type culture in MFLUCC 15-0205.

Notes - Conidiocarpus plumeriae is most typical of $C$. imperspicua (Sacc.) Cif. \& Bat., but differs in having long and hyaline ascospores, which are 5-septate at maturity, while $C$. imperspicua has short and brownish ascospores, with 4 septa at maturity. Conidiocarpus plumeriae is also similar to $C$. betle. It however differs in having subcylindrical to obovoid asci, and 5-septate ascospores, while $C$. betle has broadly clavate asci, and 4-septate ascospores, surrounded by a hyaline sheath. Phylogenetic analyses based on LSU and ITS sequence data indicate that $C$. plumeriae is closely related to $C$. betle, but is morphologically distinct.

\section{Acknowledgements}

Kevin D. Hyde thanks the Chinese Academy of Sciences, project number 2013T2S0030, for the award of Visiting Professorship for Senior International Scientists at Kunming Institute of Botany. We would like to acknowledge Thailand Research Foundation (TRG5780008) to study sooty moulds in northern Thailand.

\section{References}

Ariyawansa HA, Hyde KD, Jayasiri1 SC, Buyck B, Chethana KWT, Cui YY, Dai DQ, Dai YC, Daranagama DA, Jayawardena RS, Lücking R, Ghobad-Nejhad M, Niskanen T, Thambugala KM, Voigt K, Zhao RL, Boonmee S, Bahkali AH, Chen J, Cui BK, Dayarathne MC, Dissanayake AJ, Ekanayaka AH, Hashimoto A, Hongsanan S, Jones EBG, Larsson E, Lewis D, Li WJ, Li QR, Liu JK, Luo ZL, Maharachchikumbura SSN, Mapook A, McKenzie EHC, Norphanphoun C, Pang KL, Perera RH, Phookamsak R, Phukhamsakda C, Randrianjohany E, Senanayake IC, Singtripop C, Shang Q, Tanaka K, Tian Q, Tian CM, Tibpromma S, Verbeken A, Abdel-Wahab MA, Wanasinghe D, Wijayawardene NN, Zhang JF, Zhang H, Abdel-Aziz FA, Adamčík S, Ammirati JF, Bulgakov T, Cabral AL, Callaghan TM, Callac P, Chang CH, Coca LF, Dal-Forno M, Dollhofer V, Fliegerová K, Greiner K, Griffith GW, Ho HM, Hofstetter V, Jeewon R, Kang JC, Kirk PM, Kytövuori I, Lawrey JD, Li JHX, Liu ZY, Liu XZ, Liimatainen K, Lumbsch HT, Matumura M, Moncada B, Nuankaew S, Parnmen S, Santiago MA, Sato G, Sommai S, Song Y, Souza CAF, SouzaMotta CM, Su HY, Suetrong S, Wang Y, Wei SF, Wen TC, Yuan HS, Zhou LW, Reblova M, Fournier J, Camporesi E. 2015 - Fungal Diversity Notes 111-246 - Taxonomic and phylogenetic contributions to fungal taxa. Fungal Diversity 75, 27-274.

Batista AC, Ciferri R. 1963 - The sooty-molds of the family Asbolisiaceae. Quaderno del Laboratorio Crittogamico del Istituto Botanico dell'Università di Pavia 31, 1-229.

Bose T, Reynolds DR, Berbee MA. 2014 - Common, unsightly and until now undescribed: Fumiglobus pieridicola sp. nov., a sooty mold infesting Pieris japonica from western North America. Mycologia 106(4), 746-756. 
Cai L, Guo XY, Hyde KD. 2008 - Morphological and molecular characterization of a new anamorphic genus Cheirosporium, from freshwater in China. Persoonia 20, 53-58.

Cai L, Jeewon R, Hyde KD. 2006 - Phylogenetic investigations of Sordariaceae based on multiple gene sequences and morphology. Mycological Research 110, 137-150.

Chomnunti P, Hongsanan S, Hudson BA, Tian Q, Peršoh D, Dhami MK, Alias AS, Xu J, Liu X, Stadler M, Hyde KD. 2014 - The sooty moulds. Fungal Divers 66, 1-36.

Chomnunti P, Schoch CL, Aguirre-Hudson B, KoKo TW, Hongsanan S, Jones EBG, Kodsub R, Chukeatirote E, Bahkali AH, Hyde KD. 2011 - Capnodiaceae. Fungal Diversity 51, 103134.

Crous PW, Schoch CL, Hyde KD, Wood AR, Gueidan C, de Hoog GS, Groenewald JZ. 2009a Phylogenetic lineages in the Capnodiales. Study of Mycology 64, 17-47.

Crous PW, Verkley GJM, Groenewald JZ, Samson RA (eds). 2009b - Fungal biodiversity. CBS Laboratory Manual Series Centra albureau voor Schimmelcultures, Utrecht.

Faull JL, Olejnik I, Ingrouille M, Reynolds D. 2002 - A reassessment of the taxonomy of some tropical sooty moulds. Tropical Mycology 2, 33-40.

Hall TA. 1999 - BioEdit: a user-friendly biological sequence alignment editor and analysis program for windows 95/98/NT. Nucleic Acids Symposium Series 41, 95-98.

Höhnel F. 1910 - Fragmente zur Mykologie (Xi Mitteilung, Nr. 527 bis 573) Sitsungsber, Kaiserl. Akad Wiss Math-Naturwiss ClA bt 1 119, 618-679.

Hongsanan S, Chomnunti P, Crous PW, Chukeatirote E, Hyde KD. 2014b - Introducing Chaetothyriothecium, a new genus of Microthyriales. Phytotaxa 161(2), 157-164.

Hongsanan S, Li YM, Liu JK, Hofmann T, Piepenbring M, Bhat JD, Boonmee S, Doilom M, Singtripop C, Tian Q, Mapook A, Zeng XY, Bahkali AH, Xu JC, Mortimer PE, Wu XH, Yang JB, Hyde KD. 2014a - Revision of genera in Asterinales. Fungal Diversity 68, 1-68.

Hongsanan S, Tian Q, Bahkali AH, Yang JB, McKenzie EHC, D. Hyde KD. 2015b Zeloasperisporiales ord. nov., and two new species of Zeloasperisporium. Cryptogamie Mycologie 36(3), 301-317.

Hongsanan S, Tian Q, Peršoh D, Zeng XY, Hyde KD, Chomnunti P, Boonmee S, Bahkali AH, Wen TC. 2015a-Meliolales. Fungal Diversity 74, 1-51.

Huelsenbeck JP, Ronquist F. 2001 - MRBAYES: Bayesian inference of phylogenetic trees. Bioinformatics 17(8), 754-755.

Hughes SJ. 1972 - New Zealand fungi 17, pleomorphism in Euantennariaceae and Metacapnodiaceae, two families of sooty moulds. New Zealand Journal of Botany 10, 225242.

Hughes SJ. 1976 - Sooty moulds. Mycologia 68(4), 693-820.

Hughes SJ, Seifert KA. 2012 - Taxonomic and nomenclatural notes on sooty mould name based on species mixtures: Hormiscium handelii and Torula lecheriana. Mycoscience 53, 17-24.

Hyde KD, Jones EBG, Liu JK, Ariyawansha H, Boehm E, Boonmee S, Braun U, Chomnunti P, Crous P, Dai DQ, DiederichP, Dissanayake A, Doilom M, DoveriF, Hongsanan S, JayawardenaR, Lawrey JD, Li YM, Liu YX, Lücking R, Monkai J, Nelsen MP, Phookamsak R, Muggia L, Pang KL, Senanayake I, Shearer CA, WijayawardeneN, Wu HX, Thambugala M, Suetrong S, Tanaka K, Wikee S, Zhang Y, Hudson BA, Alias SA, Aptroot A, Bahkali AH, Bezerra LJ, Bhat JD, Camporesi E, Chukeatirote E, Hoog SD, Gueidan C, Hawksworth DL, Hirayama K, Kang JC, Knudsen K, Li WJ, Liu ZY, McKenzie EHC, Miller AN, Nadeeshan D, Phillip AJL, Mapook A, Raja HA, Tian Q, Zhang M, Scheuer C, Schumm F, Taylor J, Yacharoen S, Tibpromma S, Wang Y, Yan J, Li X. 2013 - Families of Dothideomycetes. Fungal Diversity 63, 1-313.

Index Fungorum. 2016 - http://www.indexfungorum.org/Names/Names.asp.

Jaczewski AA. 1917 - Key to Fungi. Vol. 2. (Fungi imperfecti). Petrograd 743.

Jayasiri SC, Hyde KD, Ariyawansa HA, Bhat JD, Buyck B, Cai L, Dai YC, Abd-Elsalam KA, Ertz D, Hidayat I, Jeewon R, Jones EBG, Bahkali AH, Karunarathna SC, Liu JK, Luangsa-ard JJ, Lumbsch HT, Maharachchikumbura SSN, McKenzie EHC, Moncalvo JM, Ghobad- 
Nejhad M, Nilsson H, Pang KL, Pereira OL, Phillips AJL, Raspé O, Rollins AW, Romero AI, Etayo J, Selçuk F, Stephenson SL, Suetrong S, Taylor TE, Tsui CKM, Vizzini A, Abdel-Wahab MA, Wen TC, Boonmee S, Dai DQ, Daranagama DA, Dissanayake AJ, Ekanayaka AH, Fryar SC, Hongsanan S, Jayawardena RS, Li WJ, Perera RH, Phookamsak R, de Silva NI, Thambugala KM, Tian Q, Wijayawardene NN, Zhao RL, Zhao Q, Kang JC, Promputtha I. 2015 - The Faces of Fungi database: fungal names linked with morphology, phylogeny and human impacts. Fungal Diversity 74, 3-18

Katoh K, Asimenos G, Toh H. 2009 - Multiple alignment of DNA sequences with MAFFT. Methods in Molecular Biology 537, 39-64.

Liu JK, Hyde KD, Jones EBG, Ariyawansa HA, Bhat DJ, Boonmee S, Maharachchikumbura SSN, Mckenzie EHC., Phookamsak R, Phukhamsakda C, Shenoy BD, Abdel-Wahab MA, Buyck B, Chen J, Chethana KWT, Singtripop C, Dai DQ, Dai YC, Daranagama DA, Dissanayake AJ, Doilom M, D'souza MJ, Fan XL, Goonasekara ID, Hirayama K, Hongsanan S, Jayasiri SC, Jayawardena RS, Karunarathna SC, Li WJ, Mapook A, Norphanphoun C, Pang KL, Perera RH, Peršoh D, Pinruan U, Senanayake IC, Somrithipol S, Suetrong S, Tanaka K, Thambugala KM, Tian Q, Tibpromma S, Udayanga D, Wijayawardene NN, Wanasinghe DN, Wisitrassameewong K, Zeng XY, Abdel-Aziz FA, Adamčík S, Bahkali AH, Boonyuen N, Bulgakov T, Callac P, Chomnunti P, Greiner K, Hashimoto A, Hofstetter V, Kang JC, Lewis D, Li XH, Liu XZ, Liu ZY, Matsumura M, Mortimer PE, Rambold G, Randrianjohany E, Sato G, Sri-Indrasutdhi V, Tian CM, Verbeken A, Von Brackel W, Wang Y, Wen TC, Xu JC, Yan JY, Zhao RL, Camporesi E. 2015 - Fungal diversity notes 1-110: taxonomic and phylogenetic contributions to fungal species. Fungal Diversity 72, 1197.

Nylander JAA, Wilgenbusch JC, Warren DL, Swofford DL. 2008 - AWTY (are we there yet?): a system for graphical exploration of MCMC convergence in Bayesian phylogenetics. Bioinformatics 24, 581-583.

Page RDM. 2001 - Tree View: treed rawing software for Apple Macintosh and Windows. Available at http://taxonomy.zoology.gla.ac.uk/rod/ treeview.html

Pattengale ND, Alipour M, Bininda-Emonds ORP, Moret BME, Stamatakis A. 2009 - How many bootstrap replicates are necessary? LNCS 5541, 184-200.

Reynolds DR. 1998 - Capnodiaceous sooty mold phylogeny. Canadian Journal of Botany 76, 2125-2130.

Schoch CL, Crous PW, Groenewald JZ, Boehm EW, Burgess TI, de Gruyter J, de Hoog GS, Dixon LJ, Grube M, Gueidan C, Harada Y, Hatakeyama S, Hirayama K, Hosoya T, Huhndorf SM, Hyde K D, Jones EB, Kohlmeyer J, Kruys A, Li YM, Lucking R, Lumbsch HT, Marvanova L, Mbatchou JS, McVay AH, Miller AN, Mugambi GK, Muggia L, Nelsen MP, Nelson P, Owensby CA, Phillips AJ, Phongpaichit S, Pointing SB, Pujade-Renaud V, Raja HA, Plata ER, Robbertse B, Ruibal C, Sakayaroj J, Sano T, Selbmann L, Shearer CA, Shirouzu T, Slippers B, Suetrong S, Tanaka K, Volkmann-Kohlmeyer B, Wingfield MJ, Wood AR, Woudenberg JH, Yonezawa H, Zhang Y, Spatafora JW. 2009 - A class-wide phylogenetic assessment of dothideomycetes. Studies in Mycology 64, 1-15.

Silvestro D, Michalak I, 2012 - RaxmlGUI: a graphical front-end for RAxML. Organisms Diversity \& Evolution 12, 335-337.

Tamura K, Peterson D, Peterson N, Stecher G, Nei M, Kumar S. 2011 - MEGA5: Molecular Evolutionary Genetics Analysis Using Maximum Likelihood, Evolutionary Distance, and Maximum Parsimony Methods. Molecular Biology and Evolution 28(10), 2731-2739.

Theissen F, 1916 - Mykologische Abhandlungen. Verh. der Kaiserlich- Koniglichen ZoologischBotanischen Gesell. Wien 66, 296-400.

Wijayawardene NN, Crous PW, Kirk PM, Hawksworth DL, Boonmee S, Braun U, Chomnunti P, Dai DQ, D'souza MJ, Diederich P, Dissanayake A, Doilom M, Hongsanan S, Jones EBG, Groenewald JZ, Jayawardena R, Lawrey JD, Liu JK, Lücking R, Madrid H, Manamgoda DS, Muggia L, Nelson MP, Phookamsak R, Suetrong S, Tanaka K, Thambugala KM, 
Wikee S, Zhang Y, Aptroot A, Ariyawansa HA, Bahkali AH, Bhat JD, Gueidan C, De Hoog GS, Knudsen K, McKenzie EHC, Miller AN, Mortimer PE, Wanasinghe DN, Phillips AJL, Raja HA, Slippers B, Shivas RS, Taylor JE, Wang Y, Woudenberg JHC, Piatek M, Cai L, Jaklitsch WM, Hyde KD. 2014 - Naming and outline of Dothideomycetes. Fungal Diversity 69 (1), 1-55.

Winka K, Eriksson O, Bång A. 1998 - Molecular evidence for recognizing the Chaetothyriales. Mycologia 90(5), 822-830.

Zhaxybayeva O, Gogarten JP, 2002 - Bootstrap, Bayesian probability and maximum likelihood mapping: exploring new tools for comparative genome analyses. BMC Genomics 3, 4. 